\title{
A espada pela pena: o discurso anticlerical de Dario Vellozo (1890-1905)
}

The sword for the penalty: the anticlerical discouse of Dario Vellozo (1890 - 1905)

\author{
Ernando Brito Gonçalves Junior \\ Doutor em História \\ Professor da Universidade Estadual do \\ Centro-Oeste do Paraná \\ ernandobrito@gmail.com
}

Resumo: Este texto possui como tema central de discussão analisar algumas estratégias discursivas de Dario Vellozo, importante intelectual no cenário cultural curitibano, dentro do debate travado entre anticlericais e clérigos ocorrido no Paraná no final do século XIX e início do século XX. Nesse sentido, Vellozo, que foi o principal líder do grupo anticlerical, utilizou a história, a ciência e diversos autores para legitimar seus ideais e desqualificar as propostas do grupo clerical. Utilizamos as discussões proposta pela história intelectual, levando em conta elementos textuais e contextuais dos textos analisados. Utilizamos como fontes alguns livros de Vellozo, bem como artigos escritos por ele em revistas entre os anos de 1890 a 1905, período em que o embate entre clericais e anticlericais foi mais intenso. Esperamos que essa pesquisa possa contribuir para o entendimento mais profundo da sociedade curitibana no período, bem como do movimento anticlerical ocorrido no Brasil.

Palavras Chaves: Anticlericais; História; Ciência.

\begin{abstract}
This paper has as central theme of discussion to analyze some discursive strategies of Dario Vellozo, important intellectual in the cultural scene of Curitiba, within the debate between anticlerical and clerical in Paraná in the late nineteenth and early twentieth century. In this sense, Vellozo, who was the main leader of the anticlerical group, used history, science and various authors to legitimize their ideals and disqualify the clerical group's proposals. We used the discussions proposed by intellectual history, taking into account textual and contextual elements of the texts analyzed. We used as sources some books by Vellozo, as well as articles written by him in magazines between the years of 1890 to 1905 , a period in which the clash between clerical and anticlerical was more intense. We hope that research can contribute to a deeper understanding of the society of Curitiba in the period, as well as the anticlerical movement that took place in Brazil.
\end{abstract}

Keywords: Anticlerical, History, Science. 


\section{Trajetória de Dario Vellozo}

Dario Persiano de Castro Vellozo nasceu no dia 26 de novembro de 1869, em Retiro Saudoso, bairro de São Cristóvão, Rio de Janeiro. Seus pais foram Ciro Persiano de Almeida Vellozo e Zulmira Mariana de Castro Vellozo. Segundo Tasso da Silveira, Sua infância foi “"[...] confortável, rica e formosa, na ventura de um lar abastado, de cuja superior organização lhe vieram, por certo, as linhas aristocráticas de seu temperamento fidalgo" (SILVEIRA, 1921: 12). Vellozo aprendeu suas primeiras letras com sua mãe e muito de sua educação e de seu contato com livros veio do seio familiar. D. Zulmira morreu quando Vellozo tinha apenas dez anos, em 1879, fazendo com que seu pai se tornasse sua principal referência familiar e o "grande amigo que sempre foi" (VELLOZO, 1969b: 310). Entre os anos de 1880 e 1883, iniciou seus estudos secundários no Liceu de São Cristóvão e, concomitantemente, tentou seguir a carreira militar de seu pai, matriculando-se na Escola Naval. Fez três tentativas para ser aceito, em 1882, 1883 e 1884, mas foi reprovado em todas (PILOTTO, 1969: 19).

Sua inserção no mundo do trabalho também começou cedo. Em 1884, exerceu função de aprendiz de encadernador na Oficina Lombaerts e Cia. No ano de 1885, foi aprendiz de compositor tipográfico na Oficina de Moreira, Maximino e Cia (NEGRÃO, 1928). É interessante notar que os primeiros trabalhos de Vellozo estão relacionados ao mundo da editoração, fornecendo uma bagarem de conhecimento sobre a área que seria amplamente utilizava mais tarde na criação e organização de diversas revistas e jornais.

Em agosto de 1885, Vellozo mudou-se para às terras paranaenses com seu pai e seu irmão, Tito Vellozo. Nesse mesmo ano, trabalhou como compositor tipográfico no jornal Dezenove de Dezembro, o primeiro instalado na província do Paraná (VIEIRA, 2007). É importante destacar que Ciro Vellozo, teve um papel importante na inserção de Dario no cenário intelectual de Curitiba, devido às suas atuações no estado. Além de Ciro ter sido prefeito de Curitiba (1895-1896), ele também foi presidente do Club Curitibano entre os anos de 1889 e 1891 . Sua principal contribuição nesse clube foi a fundação da Revista do Club Curitibano, em 1890, na qual divulgava textos de vários autores da cidade. Foi nas paginas dessa revista que Dario Vellozo publicou seus primeiros escritos.

Em Curitiba, Vellozo estudou no Partenon Paranaense e no Ginásio Paranaense (PILOTTO, 1969). Foi nesses estabelecimentos de ensino que Vellozo conheceu vários 
dos jovens que fizeram parte do cenário intelectual curitibano do início do século XX, como Silveira Netto, Nestor Victor, Júlio Pernetta, Ermelino de Leão, entre outros.

A partir das reuniões em sua casa e da convivência com outros jovens amantes das letras, Vellozo publicou, junto com um grupo de amigos, um periódico chamado $O$ Mosqueteiro, em 1884. No ano de 1889, Vellozo publica sua primeira obra, "Primeiros Ensaios", livro que possui três contos.

Os acontecimentos no cenário brasileiro desse período também faziam parte da pauta de discussões de Vellozo. Na Revista do Club Curitibano, ele publicou alguns textos analisando a abolição, temática sobre a qual também proferiu discursos no salão do mesmo clube, sempre se mostrando a favor da causa. A ideia de instauração de uma República era outro discurso forte no período. Segundo Vellozo, “a República surgira como uma animadora promessa à mocidade brasileira" (VELLOZO, 1969b: 110). Ele foi um ferrenho defensor desse sistema político por toda sua vida.

Vale lembrar que o final do século XIX e início do século XX foram marcados por intensas transformações no cenário nacional devido a implementação do governo republicano. Seguindo o exemplo dos grandes centros brasileiros, como São Paulo e Rio de Janeiro, o estado do Paraná também respirou esses ares de mudanças. De acordo com Etelvina de Castro Trindade e Maria Luiza Andreazza, "[...] qualquer pessoa que chegasse às cidades paranaenses no período da Primeira República encontraria, em maior ou menor grau, alguns signos da então moderna tecnologia: telégrafo, telefone ou luz elétrica; depois, automóveis e bondes" (TRINDADE; ANDREAZZA, 2001: 66).

Ao mesmo tempo em que se fazia uma intensa propaganda de ideias que defendiam - a consolidação de uma sociedade dita moderna pautada nos signos do progresso do século XIX -, os poderes públicos promoviam algumas modificações no cenário urbano daquele momento, como alargamento das avenidas, higienização do centro da cidade e ampliações da iluminação pública, do sistema de esgoto e de distribuição de água. Essas ações faziam parte da ideia de modernizar a cidade aos moldes da Belle Epóque (TRINDADE; ANDREAZZA, 2001). Essas e outras transformações, não apenas em aspectos físicos da cidade, mas também em aspectos culturais - como novas ideias educacionais, como o fortalecimento dos grupos escolares baseados nas ideias pedagógicas da chamada "lições de coisas" e várias correntes de pensamentos filosóficos, como o positivismo, higienismo e eugenismo, que adentravam de maneira mais profunda na sociedade brasileira. Essas discussões eram retratadas em 
diversos jornais e revistas do período, transformando esses órgãos em importantes veículos de divulgação.

Contudo, é digno de nota que, apesar de ser uma tentativa de modernizar Curitiba, essas mudanças não ocorriam em todo o território do município. O Centro era o principal foco de transformações, sendo que a periferia da cidade ainda continuava em um ritmo provinciano, que pouco tinha contato com os ares de modernização. Assim, Curitiba enfrentava um paradoxo: ao mesmo tempo em que alguns locais passavam por profundas mudanças para tentar se aproximar dos grandes centros, outros ainda permaneciam à margem dessas transformações. Esse paradoxo não era exclusividade de Curitiba, pois o mesmo acontecia em nível estadual e nacional. O Brasil se desenvolvia em velocidades diferentes.

Vellozo assistiu essas mudanças e atuou em alguma medida para que outras acontecessem, principalmente nas formas de pensar e de agir da sociedade. A Curitiba desse período teve um cenário intelectual rico em produção intelectual, com uma grande quantidade de livros, revistas e jornais que foram publicados nesse contexto. Houve também uma grande diversidade de opiniões, tendências e ramificações políticas, literárias e filosóficas, como, por exemplo, ideias anarquistas ${ }^{1}$, disputa de ideais entre anticlericais $^{2}$ e católicos ${ }^{3}$, a presença da literatura simbolista ${ }^{4}$, ocultista e esotérica, casas maçônicas e centros pitagóricos. Dentre essas diversas manifestações das quais Vellozo participou, nos aprofundaremos mais em seu discurso anticlerical.

Essas correntes de pensamento tiveram um importante papel no cenário político e social curitibano, fazendo com que vários intelectuais divulgassem propostas e tentassem cooptar um número maior de adeptos para seus grupos e agremiações. Assim, as várias transformações em diversos âmbitos sociais foram algumas das tintas que deram cores ao cenário curitibano do final do século XIX e início do século XX, e

\footnotetext{
${ }^{1}$ Sobre o anarquismo em Curitiba, nos remetemos a VALENTE (1992).

${ }^{2}$ Essa questão é discutida no livro de MARCHETTE (1999).

${ }^{3}$ Para maiores informações sobre os projetos educacionais católicos, ver: CAMPOS, (2002).

${ }^{4}$ Esse movimento pode ser entendido, segundo D'ONOFRIO (2002: 405), “[...] como movimento estético, o qual surgiu na França e vigorou nas duas últimas décadas do século passado, na fase da belle époque, época da boemia de Montmartre, chamados de 'poetas decadentes', tomados pela sensação do fin $d u$ siècle, acusa a crise dos ideais do complexo cultural positivista e apresenta uma nova proposta estética, fundamentada em valores espirituais. [...] Voltando, de um certo modo, à estética romântica, o Simbolismo aperfeiçoa o gosto pelo mistério das coisas, na tentativa de captar a realidade secreta do Universo, neste encontrando uma Alma e descobrindo a correspondência entre os diversos elementos da natureza, expressa artisticamente através da metáfora sinestésica: ideias aromáticas, flor canora, luz falante, cheiro das cores, etc.”.
} 
podemos perceber que Dario Vellozo ajudou a pintar esse quadro, pelo menos no que diz respeito às ideias do período.

Nesse sentido, no ano de 1895 Vellozo participa da fundação da revista $O$ Cenáculo, veículo esse que teve um grande impacto na imprensa paranaense. Foi nessa revista que Vellozo começou a escrever suas primeiras linhas anticlericais. Nessa época, ele estava adentrando mais profundamente em seus estudos ocultistas, além de começar a ter mais contato com as ideiais maçons. Vellozo foi fundador e/ou co-fundador de algumas revistas voltadas aos ideais maçons e ocultistas, como por exemplo: A Idéia (1889) Galáxia (1897) Myrto e Acácia (1916 - 1920) Phytagoras (1920) Luz de Krotona (1921 - 1927) Jerusalém (1898 - 1902) A Esphynge (1899 - 1906) Ramo de Acácia $(1908-1912)^{5}$.

No ano de 1899, Vellozo conseguiu o cargo que, sem dúvida, lhe trouxe mais prestigio no cenário paranaense. Ele foi efetivado como professor do Ginásio Paranaense e da Escola Normal. Foi ocupando esses espaços que o autor conseguiu divulgar suas ideias, ser reconhecido como um importante professor e pensador, agregando mais valor à sua imagem no período.

Em 1902, publicou o livro "Lições de História" e em 1904 a obra "No sólio do Amanha", com forte teor anticlerical. Em 1905, Vellozo escreveu o texto "Voltaire", no qual tece várias críticas à Igreja Católica, e o utiliza para confirmar e reforçar suas acusações. Em 1906, começou a ser publicada a revista A Escola, fundada pelo Grêmio dos professores do Ginásio Paranaense e da Escola Normal. Nessa revista, Vellozo expôs vários de seus projetos pedagógicos, sendo o principal local de divulgação de suas ideias relacionadas à educação. Em 1907, ele passa a dirigir a revista, da qual se afastaria em 1910. Ainda no ano de 1907, publica o livro "Compêndio de Pedagogia".

Com seu amadurecimento intelectual, Vellozo buscou alternativas para pensar a sociedade. Em 1909, fundou o Instituto Neo-Pitagórico (INP), que tinha como foco: “[...] propor uma nova ordem ética, que não fosse baseada num simples comportamentalismo, mas fundamentada na fusão das tradições Orientais e Ocidentais" (ANDRADE, 2002: 136). Nesse sentido, o INP tentou difundir a liberdade de pensamento, mostrar outras maneiras de pensar a vida com base na natureza e no cosmos.

\footnotetext{
${ }^{5}$ Para uma maior discussão a respeito da participação de Dario Vellozo na imprensa curitibana ver, entre outros: GONÇALVES JUNIOR (2016).
} 
Com o intuito de colocar em prática suas ideias educacionais, Vellozo criou em 1914, na cidade de Rio Negro, a Escola Brazil-Cívico. Essa escola possuía como base os pressupostos teóricos da Escola Moderna que tanto Vellozo defendeu, enfatizando uma educação que incluía esportes, agricultura, humanidades e iniciação científica. (ANDRADE, 2002). Apesar de todos os esforços de Vellozo e de outros participantes do projeto da Escola Brazil-Cívico, ela foi interrompida em 29 de agosto de 1914.

No início da década de 20, Dario cada vez mais se fechava no INP com seus amigos e familiares, e foi deixando aos poucos os embates públicos, como as disputas anticlericais. Já não escrevia com tanta assiduidade em revistas e jornais como fizera no início do século XX e seus textos se voltaram mais para a divulgação das ideias pitagóricas. No ano de 1923, se torna diretor da "Coluna Dórica" ${ }^{6}$, no jornal Gazeta do Povo (BEGA, 2001). Nessa coluna, além de textos de sua autoria, também eram publicados textos de membros do INP. Continuava escrevendo seus livros doutrinários, ainda com a esperança de que seus escritos alcançassem os corações e as almas dos leitores, porém, seus esforços já não reverberavam com a mesma força que outrora. No ano de 1932, se aposenta do magistério e, no ano seguinte, publica a obra "Atlântida". Essa obra possui um balanço de suas lutas e de seus sonhos. Em 1936, publica sua última obra: “Jesus Pitagórico", um diálogo entre as figuras de Jesus e de Vellozo, no qual o próprio autor recebe alguns ensinamentos.

Assim, percebemos que Vellozo foi um dos principais nomes de diversos movimentos intelectuais que se originaram em Curitiba, exercendo um grande papel no cenário da imprensa paranaense. Nesse sentido, Vellozo tentou de diversas maneiras interagir em seu contexto social, procurando colocar diversas de suas ideias em prática. Nesse sentido, enfocaremos o forte embate entre clericais e anticlericais que ocorreu em Curitiba no final do século XIX e início do século XX, tendo Dario Vellozo como o mais proeminente defensor das ideias anticlericais.

\section{A Ciência e a História na produção da Retórica Anticlerical}

O período do final do século XIX até meados do século $\mathrm{XX}$ foi marcado em Curitiba por fortes discussões entre os chamados anticlericais e o clero. Esses embates tiveram a imprensa como o principal veículo de divulgação. Foram nas páginas de

\footnotetext{
${ }^{6}$ Essa coluna parou de ser publicada apenas nos anos 1990.
} 
diversos jornais, livros, revistas e folhetos que esses dois grupos travaram inúmeros confrontos para tentar mostrar à população de maneira geral suas concepções.

Vellozo foi um dos foi um dos principais líderes do movimento anticlerical e a temática da ciência e da história estão presentes nas discussões apresentadas por ele, como argumentos para desconstruir o discurso clerical. Dessa forma, entenderemos as estratégias discursivas de Vellozo utilizando a história e tendo como um dos objetos de crítica o ensino católico.

Sobre essa temática, dialogaremos com três trabalhos. A dissertação de Tatiana Dantas Marchette "Corvos nos Galhos das Acácias: anticlericais e clericalização em Curitiba (1896-1912)". Outro trabalho pertence à Maria Lúcia de Andrade, intitulado "Educação, Cultura e Modernidade: o projeto formativo de Dario Vellozo (19061918)". O último trabalho é de Carlos Alberto Balhana, denominado "Idéias em Confronto". Tentaremos avançar as discussões em relação aos dois últimos trabalhos citados, pois, no trabalho de Andrade, apesar de estarem presentes alguns dos discursos anticlericais, a autora não investe em debater as estratégias utilizadas por Vellozo para legitimar suas ideias e para combater o clero. Da mesma forma, Balhana, apesar de mostrar as teses defendidas pelos anticlericais, focadas principalmente na figura de Vellozo, não investiga com profundidade argumentos utilizados por Vellozo para desqualificar o clero, como a utilização da ciência e da história em seu discurso anticlerical como forma de legitimar suas críticas. Assim, acreditamos que essa discussão sobre os mecanismos utilizados por Vellozo em sua luta anticlerical é fundamental para entendermos não apenas suas ideias, mas o contexto do embate entre esses dois grupos.

Um dos pontos altos do movimento anticlericalismo ocorreu no contexto iluminista na França durante o século XVIII. Dessa forma, esse movimento naquele momento, buscou “[...] combater o obscurantismo representado pelos dogmas católicos, entendidos pelos filósofos ilustrados como propagadores do fanatismo" (MARCHETTE, 1996: 5). Dentre os filósofos ilustrados, Voltaire (1694-1778) foi um dos principais defensores desses ideais, sendo um forte crítico da igreja católica e foi muito citado e utilizado como forma de legitimar as ideias anticlericais no cenário curitibano, principalmente por Vellozo.

Nosso objetivo não é traçar o histórico dos pensamentos anticlericais, portanto, nos remetemos às ideias anticlericais que circularam no contexto curitibano, mas lembramos de que tanto alguns filósofos iluministas como algumas ideias dessa vertente 
de pensamento estarão presentes nas discussões anticlericais dos paranaenses. Logo, os anticlericais curitibanos apontaram suas armas contra a influencia da igreja católica na sociedade, tendo a razão como escudo e a ciência como espada. Para definirmos mais precisamente quais eram os objetos de críticas e a quem eram os anticlericais, partimos do pressuposto indicado por Balhana. Segundo esse autor, “[...] o anticlericalimos se concentra no combate à expansão do poder dos Papas, quer religioso, como principalmente temporal. Deste modo, os anticlericais são adversários das chamadas doutrinas ultramontanas de subordinação do poder temporal à autoridade eclesiástica" (BALHANA, 1981: 12). Os anticlericais eram contra o poder papal, a intolerância religiosa, alguns preceitos da Igreja católica que divergiam da ciência e o ensino religioso. Dessa maneira, eram contrários a diversas posturas do catolicismo, principalmente ao Ultramontanismo ${ }^{7}$, e não possuíam, necessariamente, uma posição ateia (MARCHETTE, 1996). Assim, “o católico, o evangélico, o livre-pensador, podem ser anticlericais. De outro lado, o livre-pensador ou o espiritualista podem estar distanciados de quaisquer choques com o clero da Igreja Católica Romana" (BALHANA, 1981: 12).

Partimos das discussões anticlericais presentes nas páginas da revista $O$ Cenáculo, na qual Dario Vellozo tecia críticas ao ensino ministrado pelo clero católico: “[...] não incuta no espírito da infância e da juventude errôneas noções do universo, falsas noções de vida, inexatas noções de Ciência, superficial compreensão de Filosofia [...]" (VELLOZO, 1975: 218). Outra forte crítica era aos jesuítas. Em vários textos ${ }^{8}$ publicados na revista, em co-autoria com Julio Pernetta, Vellozo critica a iniciativa de catequizar os indígenas, afirmando que eles foram massacrados e perderam sua cultura.

A imprensa foi a principal arma utilizada por ambos os lados para divulgação de ideias. Dessa forma, a imprensa teve um papel essencial nos embates travados por esses dois grupos. Segundo Vellozo:

À Imprensa cabe, neste período de elaboração da psiquê nacional, importante desempenho.

\footnotetext{
${ }^{7}$ Para o autor Euclides Marchi "Reforma Ultramontana ou Ultramontanismo entende-se o processo ou o projeto implantado pela igreja Católica após a Revolução Francesa, com o objetivo de centralizar na Sé Romana, em especial na figura do papa, o poder institucional, combater as intervenções do poder civil nos assuntos da Igreja, controlar as orientações doutrinárias, ritualísticas e disciplinares, combater tudo o que representasse o mundo moderno e garantir sua sobrevivência e domínio, por meio de seu plano de recatolicização da sociedade" (MARCHI, 2013: 143).

${ }^{8}$ Esses textos foram reunidos e publicados em forma de livro, com o titulo "Pelo Aborígine", em 1911.
} 
É ela o veículo de idéias em contacto direto com a massa alfabetizada. A orientação, boa ou má, da escola, complemento do lar, lapida-se e amadurece ao contacto da Imprensa. Divulgando ideais gerais, programa de ação, sugestões úteis, para melhora coletiva, transmite ao povo a mais eficiente base cívica.

A Imprensa honesta e sincera é luz na formação nacional; é guia da opinião pública e - se compenetrada de seus fins - é Escola de todos.

Se o acervo da Imprensa é força benéfica em evolvê-lo do povo, o seu erro, refletindo na massa, perturba, destrói, corrompe e escraviza (VELLOZO; PONTES, 1943: 28).

Assim, percebemos que Vellozo sabia da importância que a imprensa possuía para divulgar suas ideias, sendo assim um ótimo mecanismo para alcançar a parte letrada da sociedade. Ao mesmo tempo, Vellozo alerta que a imprensa pode ser utilizada por outros grupos de pensamentos contrários aos seus. Da mesma forma que Vellozo conhecia a potencialidade da imprensa, o clero curitibano também estava ciente do seu poder e procurou se defender e atacar os anticlericais com a mesma arma. Um dos primeiros periódicos criados pelo clero para combater os anticlericais foi a Estrella, órgão Católico, Científico; Literário e Noticioso (1898-1905). Esse veículo contava com padres franciscanos e padres lazaristas na redação (MARCHETTE, 1996). Dessa maneira: "[...] a imprensa religiosa leva ao seio das famílias o ensino das verdades católicas, faz na praça, no café, na loja, na oficina, no restaurante, no comboio, no vapor, por toda a parte, o que o orador sagrado faz no templo" (ESTRELLA apud BALHANA, 1981: 38).

Percebemos que ambos os grupos utilizaram a imprensa em larga escala, porém, outros mecanismos foram utilizados por ambos os lados, ora para divulgar seus ideais, ora para traçar estratégias de ataque contra o outro grupo. Assim, podemos citar o primeiro "Meeting Anticlerical", realizado no dia 9 de março de 1902, no Passeio Público de Curitiba, a criação de diversas lojas maçônicas, como a Fraternidade Paranaense, Luz invisível, Acácia Paranaense, Filhas de Acácia, Apóstolos da Caridade, entre outras (MARCHETTE, 1996) e a fundação do Instituto Neo-Pitagórico.

Pelo lado católico, houve um incentivo maior para a instalação de congregações religiosas no Paraná, como por exemplo, a Congregação do Sagrado Coração de Jesus (1899), as Irmãs da Divina Providência (1903), Companhia das Filhas de São Vicente de Paulo (1904), Missionários Filhos do Imaculado Coração de Maria (1905), entre 
outras (ANDRADE, 2002), a criação de novos colégios católicos, novas igrejas, bem como o Segundo Congresso Católico Brasileiro ocorrido no ano de 1908. Segundo Euclides Marchi essas iniciativas católicas no Paraná, faziam parte de uma ação ampla implementada pela Igreja Católica no Brasil no início do século XX. Dessa forma:

O catolicismo brasileiro passaria por um processo de renovação com expressivo fortalecimento do poder episcopal e clerical, uma gradativa substituição das práticas do catolicismo laico que predominaram durante os séculos anteriores e a sacramentalização dos rituais. Um período tradicionalmente descrito pela historiografia como o da europeização da Igreja Católica ou da implantação da Reforma Ultramontana (MARCHI, 2013: 143).

Assim, o confronto entre clericais e anticlericais, longe de ter ficado apenas em torno da publicação de textos, teve contornos que abrangeram diversos cenários sociais. Porém, sem dúvida, várias das discussões que ocorriam nos encontros e nas instituições citadas acima eram retratadas na imprensa. Logo, ambos os grupos não deixavam de explicitar esses acontecimentos. Ressaltamos que em nossa pesquisa, não discutiremos os argumentos do Clero 9 nesse embate, apesar de entendermos a importância de "ouvir" seus argumentos, logo, nossa visão recairá especificamente sobre o discurso de Dario Vellozo,

Tendo a batalha se instaurado e as armas já em punho, os dois grupos em questão teciam seus argumentos. Vellozo bradava:

É dever de todo aquele que se preza de possuir uma pena - de aço ou de ouro - que importa - mostrar e demonstrar ao povo ingênuo e crédulo a impropriedade do ensino religioso, a falsidade das doutrinas de igreja romana, a esterilização do seu dogmatismo (VELLOZO, 1975: 305).

Nessa passagem de Vellozo, além de percebermos alguns de seus objetos de crítica (como ensino religioso e falsidade das doutrinas), é possível notar a questão do engajamento social do intelectual. Nesse sentido, os intelectuais do século XIX e XX

\footnotetext{
9 Para uma discussão mais profunda sobre o discurso católico ver, entro outros: MARCHI (2013);
} BALHANA (1981). 
foram os portadores de uma ideia de transformação social, ou seja, de pensar a sociedade e de propor caminhos para mudanças.

Logo, o engajamento pela educação laica tornou-se uma característica dos intelectuais, pois a educação era vista como um espaço que possibilitava a intervenção e transformação social. Por fim, "a noção de causa educacional, tão comum no discurso educacional do período, conota a ideia de projeto, de ação dirigida a fins práticos e políticos. Nessa chave de leitura, a educação [...] significou um projeto político e uma razão de engajamento dos intelectuais" (VIEIRA, 2011).

Além disso, nessa passagem de Vellozo podemos perceber que o autor acreditava pertencer a um grupo portador da verdade: os intelectuais. Esse grupo deveria ter como missão divulgar uma suposta verdade para a "população ingênua", que sem possuir as mesmas bagagens culturais e um determinado conjunto de saberes eram tratados com desdém por parte desse grupo.

Podemos identificar outros objetos de críticas dos anticlericais, mais especificamente de Dario Vellozo. Assim, os temas mais recorrentes são o ensino religioso, o celibato, o poder dos Papas, a intolerância com outras formas de pensamento, o fanatismo religioso. Logo, Vellozo procurou atacar e desqualificar esses pontos citados utilizando como armas de combate a história, a ciência e a razão, os escritos de Voltaire e a utilização de diversos outros autores para corroborar suas críticas.

Vellozo atacou diversas vezes a questão dos dogmas católicos, pois o mesmo acreditava que os dogmas afastaram a Igreja dos verdadeiros ensinamentos de Cristo e foram criados por concílios que estavam interessados em causas materiais. (VELLOZO, 1975). Assim, Vellozo entendia dogma, citando o Nouveau Larousse ${ }^{10}$, como: "artigo de crença religiosa, ensinando com autoridade e dado como sendo uma certeza absoluta" (VELLOZO, 1975: 310), terminando a citação, continua: “tornou-se contrário à Razão e à Ciência" (VELLOZO, 1975: 310). Aqui percebemos a preocupação de Vellozo em referenciar seus escritos com o objetivo de ter maior respaldo em seus argumentos, além de citar o Dicionário Larousse. Quando ele afirma que a razão e a

\footnotetext{
${ }^{10}$ Vellozo utilizou muitos dicionários Larousse de diversas edições como fonte de suas pesquisas, como o Grande Dicionário Larousse e o Nouveau Larousse, ambos com dez volumes. Essa citação ele coloca em nota, como pertencente ao Volume 3, p. 788.
} 
ciência são antagônicas ao dogma, faz referência a Leon Denis ${ }^{11}$, em sua obra "Chistianismo y Espiritismo" 12.

Para entendermos melhor essa discussão sobre os dogmas, evocamos as discussões apresentadas por Joachim Fischer. Segundo autor:

Dogmas são definições teológicas formais de enunciados fundamentais da verdade cristã, proclamadas por concílios universais ou, na Igreja Católica Romana, desde meados do século XIX, também por papas. Trata-se de enunciados fundamentais normativos que comprometem a todos/as, dentro da própria igreja. São verdades doutrinárias definidas pela igreja como expressões legítimas e necessárias da fé. Nesse sentido, o conceito de "dogma" tem seu lugar apropriado nas igrejas que representam o cristianismo dogmático, ou seja, as Igrejas Ortodoxas e a Católica Romana (FISCHER, 2008: 87).

Dessa forma, percebemos que Vellozo tinha uma visão clara sobre o conceito de dogma para a Igreja Católica, bem como a maneira com que eles foram sendo incorporados ao catolicismo. Apesar de não citar todos ${ }^{13}$, afirma que "[...] O embuste começou - Diz Leon Denis, - em 325 e terminou em 1870. Teve por base o pecado original, por cúpula a imaculada conceição e a infalibilidade. Entre a queda e a infalibilidade, decorrem: o inferno e as penas eternas, os limbos, o purgatório, a trindade, o juízo final a eucaristia" (VELLOZO, 1975: 311). Esses são alguns dos dogmas católicos que Vellozo cita, tentando afirmar que os mesmos são impostos a força e foram criados pela igreja católica como forma de controle e não condizem com as questões científicas e racionais que o mesmo defende.

Por este motivo, Vellozo afirma que "a igreja Romana, pois, perpetua o erro e o absurdo por questões de interesse. Mente, - contanto que viva; pratica a fraude, contudo que lucre" (VELLOZO, 1975: 311). É possível notar que suas críticas são mais

\footnotetext{
${ }^{11}$ Léon Denis (Foug, 1 de janeiro de 1846 - Tours, 12 de Março de 1927) foi um filósofo espírita e um dos principais continuadores do espiritismo após a morte de Allan Kardec, ao lado de Gabriel Delanne e Camille Flammarion. Fez conferências por toda a Europa em congressos internacionais espíritas e espiritualistas, defendendo ativamente a ideia da sobrevivência da alma e suas consequências no campo da ética nas relações humanas.

12 Vellozo faz a referência a uma versão em língua espanhola. Volume 1, p. 92.

13 Atualmente existem 44 dogmas declarados pela Igreja Católica, sendo divididos em "Dogmas sobre Deus", "Dogmas sobre Jesus Cristo", "Dogmas sobre a criação do mundo", "Dogmas sobre o ser humano", "Dogmas marianos", "Dogmas sobre o Papa e a Igreja", "Dogmas sobre os sacramentos" e "Dogmas sobre as últimas coisas".
} 
voltadas a instituição religiosa em só e não a religiosidade de maneira geral. $\mathrm{O}$ autor termina seu texto com uma frase de efeito, afirmando que "Roma é o erro, o crime, o fanatismo, a superstição, o dogma; é a negação da família, da ciência, da liberdade, da vida: é a morte" (VELLOZO, 1975: 311).

Para combater os dogmas, a ciência foi seu sabre mais afiado. Assim, segundo Vellozo, "a ciência analisou-os, e pronunciou irrevogável sentença; a Razão atirou-lhes a última pá de terra: apodreceram" (VELLOZO, 1975: 303). Vellozo encerra dizendo que: "a ciência dissipou o milagre, pulverizou o dogma: dogma e milagre apodreceram" (VELLOZO, 1975: 307). Essas são algumas frases de efeito, ou seja, um discurso acalorado e podemos até dizer panfletário, contudo, essas conclusões de Vellozo são baseadas em discussões teóricas levantadas por ele, com o objetivo de provar suas afirmações.

Dessa forma, Vellozo não atacou apenas alguns dogmas católicos, mas outras afirmações presentes na bíblia cristã, rebatendo afirmações com base em pesquisas feitas por outros autores, como: “O dilúvio universal apouca-se, reduz-se a inundação parcial da Ásia; - muitos o reduzem a mito, a pura lenda teogônica, inaceitáveis, baldo de provas que o demonstrarem positivamente" (VELLOZO, 1975: 226). Nessa passagem, Vellozo não cita textualmente, mas faz referencia à obra "A Criação e seus mistérios" ${ }^{14}$, de Antonio Snider-Pellegrini ${ }^{15}$, para corroborar com suas afirmações.

Outra afirmação bíblica importante é o surgimento do homem. Esse tema também é atacado por Vellozo no sentido de tentar demonstrar que a gênese do homem é mais antiga do que é defendido pela Igreja Romana. Segundo Vellozo:

O problema da origem, ou origens do homem ainda não está resolvido. As hipóteses aventadas e discutidas [...] se bem que tenham aberto à Ciência numerosos trâmites e levado os estudiosos a importantes descobertas e resultados inestimáveis, não apresentam, com tudo, solução definitiva, apesar das árduas investigações da Antropologia, da Etnologia da Lingüística (VELLOZO, 1975: 312).

\footnotetext{
${ }^{14}$ Vellozo cita o nome do livro em Francês: "La Creation et sés mystères".

15 O francês Antonio Snider-Pellegrini foi cientista e geógrafo, e elaborou, em 1858, dois mapas representando a sua versão da forma como as Américas e o continente Africano poderiam, no passado, ter estado juntos. Pellegrini foi um dos primeiros cientistas a defender explicitamente a fragmentação e deriva dos continentes vizinhos do Atlântico, baseando-se na correspondência morfológica entre as linhas da costa dos dois continentes; em observações paleontológicas relativas a certos tipos de fósseis encontrados nos dois continentes; nas obras de Ortellius e Bacon, o primeiro sugerindo que as Américas foram arrastadas para longe da África e Europa por fenômenos "catastróficos" como terremotos e cheias.
} 
Assim, Vellozo instaura a dúvida para começar a mostrar seus argumentos, sempre baseados em outros autores. Seguindo essa linha, Vellozo argumenta:

Alguns cientistas há que constatam a existência do homem desde a época terciária; outros, porém, negam essa hipótese, ou fato, admitindo apenas, então, a existência de um ser - ponto de transição do antropóide para o homem, e que deve fatalmente jazer alhures, preenchendo a lacuna existente na série animal, entre os irracionais e o ser pensante. A esse tipo, ainda não encontrado, deu Mortillet o nome de antropopiteco (VELLOZO, 1975: 312).

Foi do autor Mortillet que Vellozo tirou suas conclusões acerca da idade aproximada de 230 mil anos do surgimento do homem. Vellozo ainda faz referência a outros autores os quais afirmavam que o surgimento do homem é mais antigo do que seis mil anos que, segundo Vellozo, constam na bíblia a respeito do nascimento da espécie humana. Como por exemplo: Charles Darwin (Origens das Espécies e A Desinência do Homem), John Willian Draper ${ }^{16}$ (Histórias dos conflitos entre Religião e Ciência) e Paul Topinard ${ }^{17}$ (A Antropologia e Antropologia Geral) ${ }^{18}$.

Continuando seu argumento, Vellozo afirma que:

Fácil é constatar, os sábios não chegaram a acordo. Como quer que seja, as diversas opiniões demonstram-no, os 6.000 anos da Bíblia não satisfazem, houvesse o Homem aparecido no quaternário, no terciário ou no secundário. A Arqueologia nulificou as interpretações literárias do cômputo mosaico (VELLOZO, 1975: 314).

Assim, percebemos a preocupação de Vellozo em fazer referências a diversos autores para fomentar suas discussões, com intuito de agregar mais respeito às suas afirmações. Dessa forma, Vellozo demonstrava que suas concepções se aproximavam das ideias de outros estudiosos, fazendo com que seus pensamentos fossem mais consistentes perante seus pares em Curitiba. Era uma forma de buscar legitimidade em

\footnotetext{
${ }^{16}$ John William Draper (1811-1882) foi um cientista, filósofo, médico, químico, historiador e fotógrafo. Nascido na Inglaterra graduou-se pela University of Pennsylvania School of Medicine, em 1836. Lecionou em Hampden-Sydney College, em Virgínia. E, mais tarde, em New York University, foi eleito professor de química e botânica. Foi professor na escola de medicina de 1840 até 1850, presidente desde 1850 até 1873, e professor de química até 1881. Foi fundador da New York University Medical School.

${ }^{17}$ Paul Topinard (1830-1911, em Paris) foi médico e antropólogo. Foi vice-diretor do laboratório de antropologia da Ecole Pratique des Hautes Etudes e secretário-geral da Sociedade Antropológica de Paris. ${ }^{18}$ Todos os livros citados por Dario Vellozo estão em Francês.
} 
outros autores, por vezes mais reconhecidos no mundo intelectual. Vellozo lançou mão desse artifício em diversas de suas discussões, como continuaremos a perceber em seus outros argumentos mais à frente em nosso texto.

Seguindo com seus ataques, Vellozo comenta sobre a ideia defendida pela igreja católica de que o planeta estava no centro do universo. Assim: "a Terra deixa de ser o centro do Universo, reduzida a ínfimo papel em seio do Infinito" (VELLOZO, 1975: 226) e, mais à frente, complementa: “[...] a um impulso de Galileu, o planeta passou, do centro do universo, a girar em torno do Sol e do eixo [...]" (VELLOZO, 1975: 312). Na primeira passagem, Vellozo não cita textualmente, mas faz referência à obra chamada "Martyres da Liberdade", de Henri-Alphonse Esquiros ${ }^{19}$ e, na segunda passagem, percebemos a referência a Galileu Galilei. Apesar dessa discussão sobre a Terra como centro do universo não ser um dos pilares centrais da Igreja Católica, Vellozo, mesmo assim, tece críticas, visando mostrar alguns supostos erros cometidos pela Igreja.

Percebemos nessa discussão acima que Vellozo buscou respaldo de autores que desenvolveram pesquisas e estudos relacionados aos temas expostos, baseados nas discussões científicas da época, ou seja, tentando analisar e demonstrar empiricamente suas descobertas. Vellozo utilizou outros autores que se valeram desse método para dar um caráter científico aos seus argumentos. Assim, podemos perceber que algumas das descobertas científicas são antagônicas a determinadas afirmações bíblicas, e Vellozo, acreditando nas descobertas científicas, defendia que a partir da ciência ficava provado que alguns dogmas e algumas afirmações bíblicas seriam falsos, concluindo e defendendo que a ciência havia matado-os.

Outra forma utilizada por Vellozo para lançar críticas à Igreja Católica foi a utilização da história para apontar algumas ações consideradas por Vellozo erradas ou até como crimes praticados pela igreja. Assim, a história ganha grande importância para legitimar as discussões propostas por Vellozo.

Nesse sentido, temas como Cruzadas, Inquisição e Reforma são alguns dos acontecimentos interpretados por Vellozo para criticar a igreja romana. Vellozo afirma que, se quisermos saber a verdade desses fatos: “perguntai-o à História. E ela, inflexível e austera, vos contará de um moedeiro falso que era rei da França! E ela, imparcial e serena, vos narrará da tibiez moral de um papa que fora... quase servo de um rei!"

\footnotetext{
${ }^{19}$ Henri-Alphonse Esquiros (1812-1876), poeta francês, jornalista, escritor e político. Foi eleito em 1869 para a Assembleia Nacional, depois para o Senado. Interessado em ocultismo, o socialismo utópico e feminismo, escreveu vários textos sobre essas temáticas.
} 
(VELLOZO, 1975: 224) ${ }^{20}$. Nessa passagem, percebemos que a história possuía como função, para o autor, demonstrar a verdade e, a partir disso, Vellozo destacou determinados momentos históricos que demonstravam, segundo o autor, uma face mais violenta da Igreja Católica. Ainda nesse trecho, ele faz referência ao historiador italiano Cesare Cantu, com o objetivo de agregar mais respaldo ao seu argumento, haja vista que esse historiador gozava de credibilidade no período.

Com base nessa premissa de que a história revela a verdadeira face da Igreja Católica, Vellozo escreve:

As Cruzadas atiradas a Europa sobre a Ásia - em guerra de extermínio impiedoso - levaram, quiçá, ao coração insaciável de Roma aspirações mais ardentes, menos honestas, menos dignas, de submeter o mundo à tiara, de ter a hegemonia do mundo, como dizia possuir a hegemonia do céu (VELLOZO, 1975: 220).

Para Vellozo, as cruzadas foram uma maneira de a instituição tentar conquistar território, sem se importar com as muitas pessoas que pereceram nessa empreitada. Assim, Vellozo buscou mostrar a face mais violenta e cruel da Igreja Católica.

Seguindo sua linha de raciocínio, Vellozo comenta:

Perdidas as esperanças de conquistar persuasivamente ou pelas armas, atirando aos vórtices da tenebrosa política medieva que ensangüentava a Europa - o Vaticano -, Moleque - põe em ação meios mais eficazes, mais prontos, mais rápidos - estabelece o tribunal do SANTO OFÍCIO (VELLOZO, 1975: 222).

Nessa parte, novamente Vellozo faz referência a Cesare Cantu e lança seus olhares contra a Inquisição, afirmando que essa foi uma das piores formas da Igreja Católica impor sua dominação, matando inúmeros inocentes e impedindo o avanço da ciência, da história e da filosofia (VELLOZO, 1975).

Com esses exemplos do papel da história, percebemos que Vellozo utilizava-a como um "Tribunal da Verdade". Porém, vale lembrar que ele utiliza momentos históricos chaves para seu argumento, ou seja, esses exemplos que ele mostra são

${ }^{20}$ A referência que Vellozo faz do rei da França e do Papa dizem respeito a Felipe IV, o Belo (12681314) e Clemente V (1264-1314). O motivo de Vellozo ressaltar aspectos negativos desses personagens se deve pelo fato de que foram ambos que extinguiram a Ordem dos Templários, ordem essa que Vellozo possuía grande estima. 
escolhidos cirurgicamente, para que ele consiga construir a sua versão da Igreja Católica, afirmando que algumas ações da instituição foram totalmente contrárias aos ensinamentos de Jesus Cristo. Como já foi dito, a posição anticlerical de Vellozo era contra a Igreja Católica e de maneira nenhuma contra os ensinamentos de Jesus, com os quais Vellozo tinha grande empatia.

Se a história pode ser considerada, na perspectiva de Vellozo, como um "Tribunal da Verdade", com certeza podemos entender que Voltaire foi um dos seus principais juízes, haja vista que Vellozo utilizou os escritos do filósofo para questionar e criticar a atuação da Igreja Católica.

Vellozo cunhou uma frase que ficou muito conhecida entre os anticlericais e era muito usada: "para abater o infame, basta reeditar Voltaire" (VELLOZO, 1975: 237). Isso porque o filósofo foi um grande questionador da Igreja Católica e, segundo Vellozo, Voltaire buscou sempre a verdade e desmistificar as diversas ações da Igreja, como o milagre. Assim, Vellozo via na figura de Voltaire mais uma forma de legitimar suas críticas, já que em algumas questões, os mesmos ataques proferidos por Vellozo já haviam sido proferidos pelo filósofo.

Assim, Vellozo transcreve diversas passagens de textos de Voltaire, nos quais ele fazia acusações à Igreja. Segundo Vellozo: "Voltaire defendeu os campônios de Saint Claude e os servos do Jura; vimo-lo defender Calás, Sirven, Lally; defendeu ainda a viúva de Montbailly, Martin, o gentil-homem Morangiés; muitos outros" (VELLOZO, 1975: 251). Vellozo afirma que Voltaire defendeu essas pessoas contra os suplícios impostos pela Igreja, ou seja, condenações as quais a instituição impôs e que Voltaire tentou provar que alguns acusados eram inocentes.

Percebemos a tentativa de construção de imagem positiva de Voltaire como crítico ao posicionamento da Igreja em vários momentos. Vellozo comenta algumas críticas feitas pelo pensador francês sobre os milagres defendidos pelos padres. Assim, Vellozo cita várias passagens do livro "Tratado de Tolerância" de Voltaire, no qual o filósofo tenta mostrar a falsidade dos milagres. Nesse sentido, Vellozo afirma que:

Os excertos, transcritos ao Patriarca, indicaram realmente falsos milagres, embustes, crimes do fanatismo. Esses meios ilícitos e condenáveis, de que a igreja romana tem lançado mão para fascinar e aterrorizar o espírito das gentes, e atrair e prender numerosas ovelhas, acabaram por consumir a alma dos simples a fé generosa [...] (VELLOZO, 1975: 276). 
Entendemos que a figura de Voltaire aparece no cenário anticlerical paranaense para demonstrar que as críticas feitas à Igreja Católica não são novas e grandes pensadores já se colocaram contra as suas atuações. Vellozo defendeu alguns aspectos do ideal iluminista como a crença na ciência e a razão como forma de avanço social. Assim, Vellozo assumiu o projeto anticlerical de Voltaire, na medida em que deveria divulgar a verdade e iluminar a sociedade através do intelecto. Novamente fazemos menção à noção do intelectual com uma missão social, que, para ele, seriam a verdade e a razão à sociedade paranaense.

Assim, percebemos os três principais mecanismos utilizados por Vellozo para legitimar seu discurso. Segundo o autor: "ontem, o fanatismo que impunha; hoje, a Ciência que demonstra a Filosofia que elucida. O dogma está morto; leva por epitáfio o riso de Voltaire" (VELLOZO, 1975: 239). A ciência para Vellozo poderia comprovar a falsidade de alguns dogmas da Igreja Católica; e a história poderia demonstrar o passado "[...] rubro de sangue de milhares de vítimas que fez torturar e morrer [...]" (VELLOZO, 1975: 276) e a figura de Voltaire como um dos principais críticos da Igreja romana.

No coração da discussão anticlerical estava a disputa pelo espaço educacional em Curitiba, um dos principais motivos para a luta levantada por Vellozo. Os anticlericais aproveitaram a proclamação da República e a separação da Igreja e do Estado, bem como a lei do ensino laico, para tentar ocupar o espaço educacional curitibano. Assim, a Igreja era acusada pelos anticlericais de ser monárquica e reacionária e não condizer com os ideais republicanos. Nesse sentido, Vellozo escrevia que: “o jesuíta é anti-liberal, é reacionário, é escravocrata. [...] República e jesuitismo são incompatíveis" (VELLOZO, 1975: 230). Logo, Vellozo acreditava que o ensino religioso era incompatível com a República e deveria ser banido do país.

Vellozo tecia linhas ácidas contra o ensino religioso, que para ele era uma forma de:

Educar em fraude, na hipocrisia, na mentira consciente; dobrava sempre à vontade de outrem; coagia a pensar, julgar e agir pelo cérebro de outrem: não pode a criança hoje, progenitor amanhã acentuar ação civilizadora -, exemplo do lar, célula de reação contra elementos mórbidos e dissolventes em ação na sociedade (VELLOZO, 1975: 216). 
Vellozo sabia do importante papel que a educação exerceria na formação do indivíduo, por isso, estava disposto a empregar um ensino que ele acreditava estar correto, e o ensino religioso estava longe de ser esse modelo ideal. Assim, além de combater a Igreja e sua forma de educação, Vellozo defendeu e divulgou outra forma de ensino, utilizando novamente seus livros e a publicação de textos em revistas para divulgar suas ideias.

\section{Conclusão}

Em linhas gerais, Vellozo foi um ferrenho crítico da igreja católica em Curitiba. Percebemos que houve uma grande disputa por espaços de influencia dentro da cidade, seja em âmbito ideológico ou em espaços políticos. A disputa pelo campo da educação se tornou um elemento chave para entendermos esses conflitos, pois não se tratava apenas de uma batalha em torno do qual seria o melhor modelo de ensino, mas também acerca das influencias que essas concepções teóricas teriam futuramente no cenário educacional curitibano.

Logo, os argumentos levantados por Vellozo estão em sintonia com diversos pensamentos marcantes do século XIX e início do século, como a crença na ciência, como verdadeira forma de conhecimento. A utilização de diversos autores releva sua faceta cosmopolita e corrobora com sua fé científica, haja vista que utiliza autores que se valem de métodos científicos.

Por fim, foi possível percebermos algumas das estratégias utilizadas por Dario Vellozo no combate anticlerical em Curitiba. Assim, o conhecimento da história e da ciência são as principais armas levantadas por Vellozo para combater algumas ideias da Igreja Católica, elevando essas formas de conhecimento a outro patamar, de defensoras e legitimadoras de ideias.

\section{Referências bibliográficas}

ANDRADE, Maria Lucia (2002). Educação, cultura e modernidade: o projeto formativo de Dario Vellozo. Dissertação (Mestrado em Educação) - Universidade Federal do Paraná, Curitiba.

BALHANA, Carlos, Alberto (1981). Ideias em confronto. Curitiba: Secretaria da cultura e do esporte. Grafipar. 
BEGA, Maria Tarcisa Silva (2001). Sonho e Invenção no Paraná: geração simbolista e a construção de identidade regional. Tese (doutorado em Sociologia). Universidade de São Paulo, São Paulo.

BOSI, Alfredo (2006). Historia concisa da literatura brasileira. São Paulo: Cultrix.

CAMPOS, Nevio de (2002). Laicato Católico: o papel dos intelectuais no processo de organização do projeto formativo da Igreja Católica no Paraná (1926-1938). Dissertação (Mestrado em Educação) - Universidade Federal do Paraná, Curitiba.

CORRÊA, Amélia Siegel (2006). Imprensa e Política no Paraná: prosopografia dos redatores e pensamento republicano no final do século XIX. Dissertação (Mestrado em Sociologia) - Universidade Federal do Paraná, Curitiba.

DENIPOTI, Cláudio (2001). Um homem no mundo do livro e da leitura. Revista de História Regional (UEPG), Ponta Grossa, ano 6, v. 2, pp. 75-91.

D'ONOFRIO, Salvatore (2002). Literatura Ocidental. Autores e obras fundamentais. 2. ed. São Paulo: Ática.

FISCHER, Joachim (2008). História dos dogmas, história da teologia, história do pensamento cristão Considerações sobre alguns conceitos da historiografia eclesiástica. Revista Estudos Teológicos, ano 48, n. 1, pp. 83-100.

GONÇALVES JUNIOR, Ernando Brito (2016). O Impresso como estratégia de intervenção social: educação e história na perspectiva de Dario Vellozo (18851937). Curitiba, Appris.

MARACH, Caroline (2007). Inquietações modernas: discurso educacional $e$ civilizacional no periódico "A Escola” (1906-1910). 2007. Dissertação (Mestrado em Educação) - Universidade Federal do Paraná, Curitiba.

MARCHETTE, Tatiana Dantas (1996). Corvo no galho das acácias: o movimento anticlerical em Curitiba (1896-1912). Curitiba: Aos Quatro Ventos.

MARCHI, Euclides (2013). Anticlericais \& Ultramontanos: embates na paróquia. Revista Brasileira de História das Religiões. Maringá: UEM, jan, V. 5, pp. 139154.

MYSKIW, Antonio Marcos (2008). Curitiba, "República das Letras" (1870-1920). Revista eletrônica Reflexões em História. Dourados, v. 2, n. 3, p. 1-27, 2008. Disponível em: <http://www.historiaemreflexao.ufgd.edu.br/Curitiba_republica_das_letras.pdf>. Acesso em: 01 mar. 2016.

MURICY, Andrade (1973). Panorama do movimento simbolista brasileiro. 2. ed. Brasilia: Conselho Federal de Cultura: INL.

NEGRÃO, Francisco de (1929). Genealogia Paranaense. Curitiba: Impressora Paranaense.

PEREIRA, Luis Fernando Lopes (1998). Paranismo: O Paraná inventado; cultura e imaginário no Paraná da I República. 2. ed. Curitiba: Aos Quatro Ventos.

PILOTTO, Erasmo (1969). Dario Vellozo: cronologia. Curitiba: s.ed.

SILVEIRA, Tasso da (1921). Dario Vellozo: Perfil Espiritual. [S.I.: s.n]

TRINDADE, Etelvina Maria de Castro; ANDREAZZA, Maria Luiza (2001). Cultura e Educação no Paraná. Curitiba: SEED.

VALENTE, Silza Maria Pazello (1992). A presença rebelde na Cidade Sorriso: contribuição ao estudo anarquista em Curitiba (1890-1920). 1992. Dissertação (Mestrado em Educação) - Universidade Estadual de Campinas, Campinas.

VELLOZO, Dario (1969a). Obras I. Curitiba: Instituto Neo-Pitagórico, 1V. (1969b). Obras II. Curitiba: Instituto Neo-Pitagórico. 2V. (1969c). Obras III. Curitiba: Instituto Neo-Pitagórico. 3V. (1975) Obras IV. Curitiba: Instituto Neo-Pitagórico. 4v. 
(1980). Ciências Ocultas. In: CAROLLO, Cassiana Laerda (org.). Decadismo e Simbolismo no Brasil: crítica e poética. Rio de Janeiro: Livros Técnicos e Científicos: INL.

; PONTES, Gustavo (1943). Terra das Araucárias. Curitiba: Instituto NeoPitagórico.

VIEIRA, Carlos Eduardo (2008). Intelligentsia e intelectuais: sentidos, conceitos e possibilidades para a história intelectual. Revista brasileira de História da educação. Campinas: Autores Associados, Janeiro/abril, n. 16, pp. 63-85. (2007). Jornal Diário como fonte e como tema para a pesquisa em História da Educação: um estudo da relação entre imprensa, intelectuais e modernidade nos anos de 1920. In: OLIVEIRA, Marcus Aurélio Taborda de. Cinco estudos sobre a História da Educação. Belo Horizonte: Autêntica.

(2011). Erasmo Pilotto: identidade, engajamento político e crenças dos intelectuais vinculados ao campo educacional no Brasil. In: ALVES, C.; LEITE, J. L. (Org.). Intelectuais e história da educação no Brasil: poder, cultura e políticas. 1. ed. Vitória: EDUFES, pp. 25-54.

Artigo recebido em 20 de julho de 2016.

Aprovado em 30 de maio de 2017.

DOI: 10.12957/intellectus.2017.24733 